\title{
Pengaruh Personal Selling, dan Slogan Iklan Terhadap Brand Awareness Produk Yakult
}

\author{
Rahayu Efendi dan Mashadi \\ Program Studi Manajemen, Institut Bisnis dan Informatika Kesatuan \\ E-Mail: mashadi@ibik.ac.id
}

ABSTRACT

Yakult is the first probiotic drink in Indonesia since 1991. Until now, Yakult is still the number one pioneer of fermented milk drinks in Indonesia. The purpose of this study is to determine the effect of Personal Selling on Brand Awareness, determine the effect of Advertising Slogans on Brand Awareness, and to determine the effect of Personal Selling and Advertising Slogans on Brand Awareness together. This research was conducted with a quantitative descriptive approach with a random sampling method. The number of respondents in the study were 100 respondents who will be analyzed using SPSS 22 software. The statistical method used is multiple linear regression by testing the classical assumptions, correlation coefficients and coefficient of determination, and conducting hypothesis testing (ftest and t test). The results showed that Personal Selling did not affect Brand Awareness positively and significantly, while Advertising Slogans affected Brand Awareness positively and significantly. Meanwhile, together with Personal Selling and Advertising Slogans, it affects Brand Awareness. If the personal selling and advertising of a company is getting better, then the potential Brand Awareness of the public towards the company will also increase, conversely if consumers do not have an interest in personal selling or advertising carried out by the company, the potential Brand Awareness owned by consumers will also be low .

Keywords: Brand Awareness, Personal Selling, Ad Slogans
Submitted: APRIL 2020

Accepted: AGUSTUS 2020

\begin{abstract}
ABSTRAK
Yakult merupakan minuman probiotik pertama di Indonesia sejak tahun 1991. Hingga saat ini Yakult masih menjadi pelopor minuman susu fermentasi pertama nomor satu di Indonesia. Tujuan penelitian ini adalah mengetahui pengaruh Personal Selling terhadap Brand Awareness, mengetahui pengaruh Slogan Iklan terhadap Brand Awareness, dan untuk mengetahui pengaruh Personal Selling dan Slogan Iklan terhadap Brand Awareness secara bersama-sama. Penelitian ini dilakukan dengan pendekatan deskriptif kuantitatif dengan metode random sampling. Jumlah responden dalam penelitian sebanyak 100 responden yang akan dianalisis dengan menggunakan perangkat lunak SPSS 22. Metode statistik yang digunakan adalah regresi linier berganda dengan melakukan uji asumsi klasik, koefisien korelasi dan koefisien determinasi, serta melakukan uji hipotesis (uji $\mathrm{f}$ dan uji t). Hasil penelitian menunjukkan bahwa Personal Selling tidak mempengaruhi Brand Awareness secara positif dan signifikan, sedangkan Slogan Iklan mempengaruhi Brand Awareness secara positif dan signifikan. Sementara itu secara bersama-sama Personal Selling dan Slogan Iklan berpengaruh terhadap Brand Awareness. Jika personal selling dan iklan dari sebuah perusahaan semakin baik, maka potensi Brand Awareness masyarakat terhadap perusahaan tersebut juga akan semakin meningkat, sebaliknya jika konsumen tidak memiliki ketertarikan terhadap personal selling maupun iklan yang dilakukan oleh perusahaan maka potensi Brand Awareness yang dimiliki oleh konsumen juga akan rendah.
\end{abstract}

Kata kunci: brand awareness, personal selling, slogan iklan

\section{JIMKES}

Jurnal Ilmiah Manajemen Kesatuan
Vol. 8 No. 2,2020 pp. 127-137 IBI Kesatuan ISSN 2337-7860 
Brand Awareness and Promotional Mix

128

\section{PENDAHULUAN}

Dalam pertumbuhan bisnis didunia suatu perusahaan dituntut agar bisa menciptakan sebuah produk yang mampu bersaing dengan produk lain apabila ingin tetap bertahan dalam persaingan bisnis. Suatu perusahaan bisnis dapat menjadi pemenang dalam persaingan bisnisnya apabila perusahaan tersebut mampu menjaring pelanggan sebanyakbanyaknya dan dapat dipastikan perusahaan tersebut dapat memperoleh keuntungan yang besar. Pada dasarnya semua perusahaan bertujuan akhir yang sama yaitu untuk memperoleh keuntungan dengan cara menawarkan suatu produk yang sudah dibuat yang dapat memuaskan keadaan pasar dalam jangka waktu tertentu. Dalam pemasaran modern, masyarakat didunia ini dituntut untuk mengetahui keadaan produk yang bermutu dan layak untuk di konsumsi, dan perusahaan juga dituntut untuk aktif dalam melakukan komunikasi dengan konsumen untuk mengetahui apa yang menjadi kebutuhan dan keinginan konsumen. Suatu persaingan bisnis sangat tajam keberadaannya, dari waktu ke waktu dengan jumlah penduduk Indonesia yang besar menjadikan suatu perusahaan berlomba-lomba untuk memasarkan produknya dengan menggunakan berbagai strategi pemasaran.

Banyak hambatan yang harus di lewati oleh suatu perusahaan bisnis salah satunya persaingan antara perusahaan yang sejenis. Perusahaan tersebut harus menggunakan suatu strategi yang cocok untuk mengatasi pasar persaingan. Syarat untuk wajib dipenuhi oleh suatu perusahaan untuk memenangkan pasar persaingan adalah perusahaan tersebut harus sukses mendapatkan konsumen dan mempertahankan konsumen sebanyakbanyaknya. Hal yang harus diketahui oleh perusahaan yaitu harus memahami perilaku konsumen apabila ingin mendapatkan dan mempertahankan konsumen. Perusahaan yang mampu memasarkan produknya dengan baik dan mengerti akan permintaan konsumennya, maka perusahaan tersebut tidak menutup kemungkinan akan menenangkan pasar persaingan dunia usaha.

Pada prinsipnya keberadaan produk di pasar memiliki fungsi sebagai pengganti (subtitusi) bagi produk yang lain, oleh karenanya perusahaan perlu mengedepankan pemikiran tentang; bagaimana membuat konsumen mengenali dan menyadari keberadaan perusahaan melalui produk mereka? Dengan kata lain perusahaan harus mampu menemukan dan merumuskan sebuah poin pembeda antara produk perusahaan dengan produk para pesaing, karena apabila tidak mampu menemukannya maka apapun keunggulan produk perusahaan tetap saja akan dianggap sama oleh konsumen dengan produk yang lain (pesaing) di pasar. Salah satu konsep pemikiran yang dapat dipergunakan sebagai pembeda suatu produk oleh perusahaan adalah brand (merek). Apabila kita menggunakan brand (merek) sebagai pembeda suatu produk maka perumusan dan pemosisian sebuah brand (merek) merupakan sebuah tahapan penting bagi perusahaan. Nilai penting dari suatu merek pada prinsipnya adalah terwujudnya kesadaran (awareness) yang merupakan core competency bagi perusahaan karena tolok ukur kekuatan sebuah merek adalah sebuah gambaran situasi dan kondisi dimana konsumen merasa sangat mengenal dan memahami produk, baik itu dari sisi kualitas dan atau ciri yang dimiliki oleh perusahaan di antara merek yang ada dan ataudi tawarkan di pasar. Brand awareness merupakan alat ukur tambahan yang ada pada konsumen mengenai produk perusahaan. Brand awareness membawa banyak keuntungan pada perusahaan, yaitu kemungkinan terjadinya pembelian ulang dan rekomendasi produk pada teman dan relasi-relasi konsumen (Xiaojuan Ou dan Banerjee, 2009).

Dalam hal ini promosi merupakan salah satu faktor utama penunjang keberhasilan sebuah perusahaan untuk memasarkan produknya selain dilihat dari bagaimana perilaku konsumen terhadap produk tersebut. Promosi sendiri adalah "suatu komunikasi informasi penjual dan pembeli yang bertujuan untuk mengubah sikap dan tingkah laku pembeli yang tadinya tidak mengenal menjadi mengenal sehingga menjadi pembeli dan tetap mengingat produk tersebut" (Saladin, 2003). Sebagai alat promosi, suatu perusahaan menggunakan promosi penjualan atau yang lebih dikenal dengan promosi penjualan. Metode ini digunakan untuk membujuk calon pembeli agar membeli produk yang dihasilkan dan ditawarkan perusahaan. Dengan teknik promosi penjualan yang 
tepat konsumen akan lebih tertarik untuk membeli produk tersebut. Promosi merupakan arus informasi atau persuasi satu arah yang dibuat untuk mengarahkan seseorang atau organisasi kepada tindakan yang menciptakan pertukaran dalam pemasaran (Swastha \& Sukotjo, 2007). Promosi berkaitan dengan upaya untuk mengarahkan seseorang agar dapat mengenal produk perusahaan, lalu memahaminya, berubah sikap, menyukai, yakin, kemudian akhirnya membeli dan selalu ingat akan produk tersebut (Tjiptono, 1997). Sedangkan bentuk-bentuk promosi ada empat macam, meliputi: periklanan, personal selling, publisitas, dan promosi penjualan (Tjiptono,1997). Dari keempat bentuk promosi tersebut, yang paling efektif adalah melalui iklan. Sedangkan iklan yang efektif adalah iklan yang mampu untuk berkomunikasi (menarik, daya tarik membaca, daya tarik sikap, mudah diingat kembali, dilihat, diperhatikan, paling banyak dibaca) dan pengaruh penjualannya terhadap apa yang telah diiklannya tersebut (Tjiptono,1997). Iklan adalah sumber informasi utama dalam pengambilan keputusan. Kegiatan periklanan adalah salah satu alat promosi utama yang sering digunakan untuk mengarahkan komunikasi yang bersifat membujuk kepada yang ditujunya, yang mana kegiatan periklanan merupakan salah satu faktor yang penting dan erat hubungannya dengan selera dan kepentingan konsumen.

Personal selling sebagai subelemen promosi, mempunyai dampak sangat berbeda dengan subelemen promosi lain, misal bombardir periklanan di media masa atau dengan kegiatan promosi visual dan display lainnya yang bersifat publikasi. Personal selling digunakan agar para calon konsumen lebih dapat mengetahui produk yang akan dibeli serta. Di samping itu, dapat berdampak positif bagi perusahaan karena menjadi sumber informasi perusahaan yang dapat mengetahui apa yang diinginkan oleh konsumen. Dengan strategi promosi yang tepat konsumen akan mengingat produk yang akan dipasarkan (kesadaran merek). Dengan kesadaran konsumen terhadap produk yang dipasarkan maka perusahaanakan jauh lebih mudah memasarkan produk tersebut. Artinya dengan sedikit saja promosi konsumen sudah mengetahui bahwa produk tersebut adalah produk dari perusahaan tertentu.

Adapun cara lain dari perusahan yaitu dengan cara memberikan slogan pada pruduknya. Slogan iklan merupakan sebuah pesan yan terbentuk lisan dalam sebuah iklan. Pesan yang menarik dan mudah diingat akan mempermudah seseorang mengingat sumber pesan dalam hal ini ialah produk yang beriklan. Pesan iklan yang dikemas menarik dan mudah diingat ini disajikan menjadi slogan yang ternyata setelah dilakukan penelitian mempunyai efek yang positif terhadap pembentukan Brand awareness pada khalayak yang diuji. Dengan reputasi produk yakult yang sudah lama dikenal oleh masyarakat Indonesia. Namun, kesemuanya memiliki persamaan dalam membangun iklan niaga produk, salah satu hal yang paling utama yang harus diperhatikan adalah pembuatan slogan atau tagline dari produk tersebut, slogan yang unik dan menarik yang dapat mengikat dipikiran konsumen. Produsen Yakult gencar mengkampanyekan iklan bertajuk "Cintai Ususmu minum Yakult tiap hari" yang berdurasi kurang lebih 2 menit dengan tujuan agar lebih banyak pemirsa yang melihat iklan tersebut, sehingga pesan dalam iklan lebih mengena. Ditengah banyaknya produk yang ditawarkan saat ini konsumen membutuhkan suatu pegangan dalam memilih, oleh sebab itu, peran Brand bagi konsumen saat ini adalah tempat rujukan terpercaya dalam memilih begitu banyak produk ditengah keterbatasan waktu yang mereka miliki.

Yakult adalah minuman susu frementasi yang mengandung bakteri Lactobacillus casei shirota strain. Setiap botol yakult mengandung bakteri Lactobacillus casei shirota strain yang dapat mencapai usus dalam keadaan hidup sehingga dapat membantu menjaga kesehatan pencernaan dan menekan pertumbuhan bakteri merugikan didalam pencernaan. Kotler dan Amstrong (2010) menyatakan bahwa dalam membuat pesan harus bersifat rasional, emosional, dan juga moral. Rasional menunjukan keterkaitan antara keinginan dengan barang yang ditawarkan. Emosional menunjukan bahwa pesan yang disampaikan dapat berkaitan atau berpengaruh terhadap emosi audience, sentuhan moral berkaitan dengan kepekaan audience terhadap benar dan salah. Iklan menjadi tahap yang penting yang sama pentingnya dengan tahap-tahap lain dalam proses pemasaran.
Brand Awareness and Promotional Mix

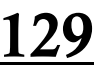


Brand Awareness and Promotional Mix

130
PT.Yakult merupakan perusahaan manufaktur yang bergerak dalam bidang produksi susu fermentasi. Cara penyampaian pesan dalam iklan Yakult untuk Indonesia ini sangat menarik dan ada pergerakan/tarian yang menyenangkan, dari gambar dan kata-kata yang layak untuk ditonton yang mana dengan bergerak atau menari itu sendiri dengan membuat orang sehat ditambah lagi dengan mengonsumsi Yakult, hal itu agar membuat audiens atau konsumen berpikir bahwa yakult ini membawa pengaruh positif bagi kehidupan sehari-hari setiap orang yang mengkonsumsi. Kualitas produk dalam minuman Yakult sudah terbukti dengan adanya manfaat Yakult bagi kesehatan tubuh manusia adalah meningkatkan jumlah bakteri dalam usus, memperlancar pencernaan, meningkatkan imunitas dan kekebalan tubuh, mengurangi racun dalam usus, mencegah perut kembung, meningkatkan lemak, mengobati maag, tidak mengandung pengawet, baik dikonsumsi ibu hamil, mencegah munculnya penyakit-penyakit kronis, dan mencegah eksim.

Data Top Brand Award tahun 2017, 2018, dan 2019 menunjukan bahwa Yakult merupakan satu-satunya minuman susu fermentasi yang selalu meraih predikat Top Brand dan selalu meraih angka mencapai $80 \%$ mengalahkan para pesaingnya seperti Cimory, Vitacharm, dan Calpico.

Tabel 1. Data top Brand Susu Fermentasi bermerk dalam kemasan 2017 - 2019

\begin{tabular}{|c|c|c|c|c|}
\hline \multicolumn{5}{|c|}{ Susu Fermentasi Bermerk dalam Kemasan } \\
\hline MEREK & 2019 & 2018 & 2017 & Keterangan \\
\hline Yakult & $89,7 \%$ & $70,1 \%$ & $78,6 \%$ & TOP \\
\hline Calpico & 10,3 & $2,9 \%$ & $1,1 \%$ & \\
\hline Cimory & & $16,3 \%$ & $10,4 \%$ & TOP \\
\hline Vitacharm & & $1,7 \%$ & $3,2 \%$ & \\
\hline Activia & & $1,6 \%$ & $1,8 \%$ & \\
\hline
\end{tabular}

Sumber: www.topbrand-award.com

Berdasarkan data Tabel 1. di atas menunjukan bahwa Yakult pada tahun 2017 sampai dengan thun 2019 mendapatkan predikat Top Brand secara tiga tahun berturut-turut dengan angka mencapai di atas $70 \%$ dan selalu mengalahkan para pesaingnya dengan selisih jarak yang cukup jauh. Penjualan yakult menurun dari tahun $2017 \mathrm{ke} 2018$ sebesar $8,5 \%$, hal ini tetap mengukuhkan Yakult sebagai produk susu frementasi bermerek dalam kemasan dengan predikat Top Brand. Akan tetapi, penurunan yang dialami PT.Yakult Indonesia Persada pada tahun 2017 ke tahun 2018 tersebut bahwa strategi pemasaran iklan yang digunakan perusahaan masih kurang efektif dan kualitas produk dari produk susu fermentasi Yakult kembali dipertanyakan. Fenomena yang terjadi dalam penelitian ini mengenai Personal selling dan Slogan Iklan adalah dimana factor kualitas produk merupakan satu dari beberapa element penting yang mempengaruhi kesadaran merek itu sendiri. Yang dilakukan oleh PT.Yakult dapat dikatakan kurang efektif karena hal itu terbukti dari data Top Brand menunjukan bahwa hal yang mempengaruhi penurunan tersebut adalah kurang efektifnya periklanan yang dijalankan oleh PT. Yakult Indonesia persada tersebut.

PT. Yakult Indonesia Persada adalah perusahaan yang produknya bergerak dibidang susu berfermentasi. Dalam produknya tersebut Pt. Yakult Indonesia Persada menggunakan lebih dari 6,5 milyar bakteri Lactobacillus Casei Shirota strain hidup, susu bubuk skim, glukosa dan sunkrosa, perisa Yakult, dan air yang sudah sesuai denga harapan konsumennya Yakult merupakan produk yang berkualitas dan sudah sesuai dengan harapan konsumennya. Yakult merupakan produk yang berkualitas dan sudah diakui oleh para konsumennya. Hal ini dibuktikan dengan diraihnya melalui penghargaan Top Brand Award 2017, 2018, dan 2019 Yakult selalu menempatkan namanya dengan predikat TOP.

Ada beberapa masalah juga yang membuat suatu poduk tersebut menurun. Masalah yang pertama, adalah kurangnya penyebaran distribusi produk Yakult di Indonesia. Hingga saat ini, distribusi produk Yakult hanya dapat mencakup wilayah Indonesia 
bagian barat dan baru mulai merabah kewilayah Indonesia bagian tengah. Hal ini mungkin disebabkan oleh jumlah pabrik Yakult yang hanya ada 2 di Indonesia dan hanya didirikan di Pulau Jawa sehingga menghambat proses distribusi ke wilayah yang lebih jauh lagi sehingga penyebaran dirasa masih belum merata terutama untuk Indonesia bagian Timur. Masalah kedua adalah minimnya fasilitas yang berguna untuk menjaga kondisi Yakult yang harus berada dalam suku 0-10 celcius. Untuk Yakult sendiri hanya disediakan cooler boox berupa tas kecil yang belum tentu dapat menjaga suhu produk sesuai dengan ketentuan. Apalagi Yakult diharuskan untuk berjalan jauh dibawah panasnya matahari sehingga berpotensi untuk merubah suhu dari cooler boox. Selain itu, banyak warung-warung yang menjual Yakult diluar kulkas sehingga dapat dipastikan kualitas dari Yakult ini menurun tanpa ada bisa dilakukan control yang lebih ketat untuk warung atau toko yang menjual Yakult diluar ketentuan.

Dari kedua masalah tersebut, ada beberapa solusi yang dapat diaplikasikan untuk mengatasi permasalahan tersebut. Untuk masalah yang pertama dapat diatasi dengan mendirikan pabrik didaerah yang lebih strategis untuk pendistribusiannya diwilayah Indonesia bagian timur. Tempat strategis yang di maksud adalah dengan membangun pabrik di daerah pulau Sulawesi. Selain itu dapat juga dengan menambah titik-titik pendistribusiannya dengan memaksimalkan transportasi untuk mengirim produk ke daerah yang belum mendapatkan distribusi Yakult. Kemudian untuk masalah kedua dapat diatasi dengan melakukan inovasi untuk cooler boox yang digunakan oleh Yakult agar dapat menjaga suhu Yakult tetap konstan dan dapat diontrol. Dan untuk masalah warung-warung yang tidak memenuhi syarat dapat dilakukan dengan melakukan penyuluhan kepada para konsumen agar mengerti standar dari produk yang baik adalah produk Yakult yang berada pada suhu 0-10 celcius. Sehingga hal tersebut akan menciptakan konsumen dapat dilakukan controlling dengan bantuan Yakult untuk melaporkan kepada perusahaan jika ada warung ada toko yang tidak menjaga kualitas produk Yakult. Untuk membangun brand awareness Yakult yang kuat, dapat dilakukan dengan meningkatkan efektifitas periklanan melalui iklan yang memiliki slogan dan juga melakukan personal selling. Hal itu dilakukan agar iklan tersebut dapat mengenalkan dan menyadarkan konsumen akan suatu merek, serta tertanam kuat dalam benaknya. Karena menurut Howard (1994) Sikap konsumen terhadap merek dapat timbul setelah mengenal merek atau langsung mendengar pesan iklan (informasi) yang disampaikan produsen.

Berdasarkan latar belakang diatas, tujuan penelitian ini adalah sebagai berikut :

1. Untuk mengetahui pengaruh personal selling terhadap brand awareness?

2. Untuk mengetahui pengaruh slogan Iklan terhadap brand awareness?

3. Untuk mengetahui pengaruh personal selling dan slogan iklan secara bersama-sama berpengaruh terhadap brand awareness?

\section{METODE PENELITIAN}

Metode penelitian ini adalah metode asosiatif yaitu penelitian yang dilakukan untuk mencari hubungan antara satu variabel dengan variabel yang lainnya. Variabel dependen yaitu variabel yang nilainya dipengaruhi oleh variabel independen yang dijadikan sebagai variabel dependen dalam penelitian ini adalah Brand Awareness (Y). Variabel independen adalah variabel yang mempengaruhi variabel dependen, baik yang pengaruhnya positif maupun yang pengaruhnya negatif (Suhartanto, 2014). Variabel independen dalam penelitian ini terdiri dari : Personal Selling $\left(X_{1}\right)$ dan Slogan Iklan $\left(X_{2}\right)$ Lokasi penelitian ini dilaksanakan di kota Bogor. Penelitian dilakukan pada bulan Januari sampai bulan April 2019. Populasi yang digunakan dalam penelitian ini adalah pada konsumen Yakult di Kota Bogor yang jumlahnya belum teridentifikasi secara kuantitatif. Untuk menentukan sampel dari populasi digunakan perhitungan maupun acuan tabel yang dikembangkan para ahli. Secara umum, untuk penelitian korelasional jumlah sampel minimal untuk memperoleh hasil yang baik adalah 30, sedangkan dalam penelitian eksperimen jumlah sampel minimum 15 dari masing-masing kelompok dan untuk
Brand Awareness and Promotional Mix 
Brand Awareness and Promotional Mix

132 penelitian survei jumlah sampel minimum adalah 100. Maka dengan ini peneliti mengambil sampel 100 orang responden yang mengkonsumsi produk Yakult di kota Bogor.

Pada penelitian ini skala yang digunakan untuk menghitung masing-masing indikator adalah skala ordinal. Dimana ditentukan item-item yang relevan dengan apa yang diketahui kemudian responden diminta untuk memberikan jawaban-jawaban yang paling sesuai. Skala Likert merupakan skala yang dipakai untuk mengukur sikap, pendapat atau persepsi seseorang tentang fenomena sosial.Skala ini digunakan karena mudah dibuat, bebas memasukan pernyataan yang relavan.Pernyataan ini menggunakan teknik agreedisagreescale dengan skala 5 yang menunjukkan setuju atau tidak setuju terhadap pernyataan tersebut.Skala pengukuran ini menunjukkan bahwa jika nilainya mendekati satu berarti semakin tidak setuju. Sebaliknya jika mendekati angka lima berarti semakin setuju. Kemudian dilakukan uji kualitas data yang meliputi uji validitas, uji reliabilitas dan uji asumsi klasik. Uji korelasi berganda dan analisis regresi berganda digunakan untuk melakukan analisis asosiatif antara variable independent dan variable dependen.

\section{HASIL DAN PEMBAHASAN \\ Karakteristik Responden}

Penelitian telah dilakukan dengan menyebarkan kuesioner kepada 100 orang responden yang diambil secara acak di daerah Kota Bogor. Karakteristik responden meliputi jenis kelamin, usia, pekerjaan, pendapatan dan berapa kali Yakult yang diminum dalam waktu satu minggu. Hasil analisis data untuk karakteristik responden secara rinci dijelaskan sebagai berikut:

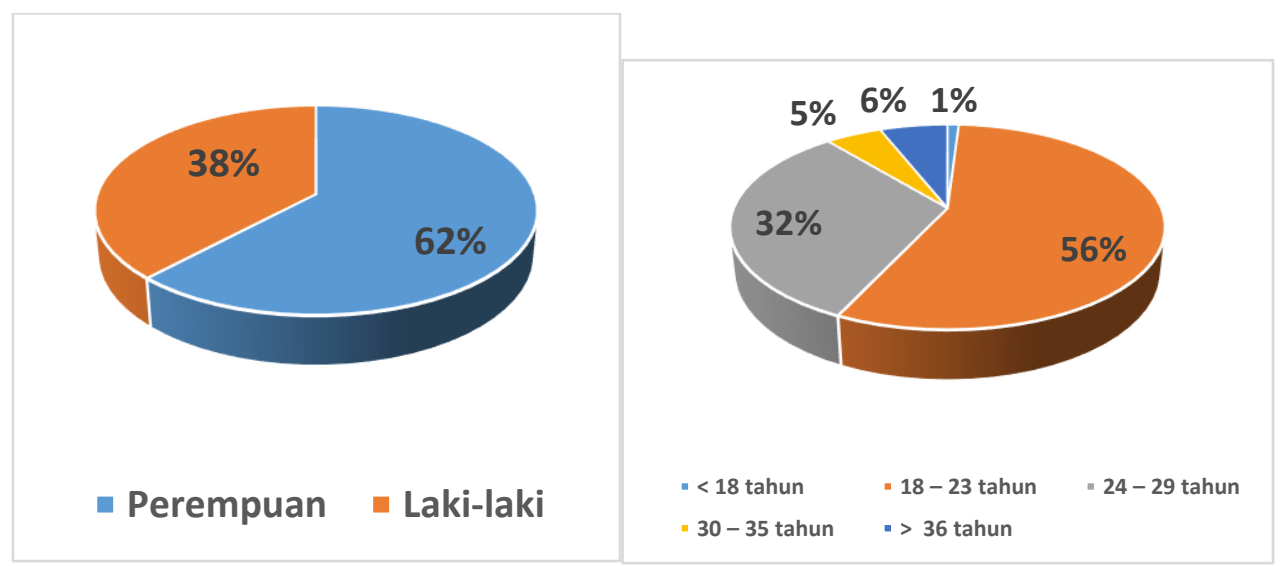

Gambar 1 Sebaran Responden berdasarkan Jenis Kelamin dan Usia

Analisis terhadap responden berdasarkan jenis kelamin dilakukan untuk mengetahui proporsi jenis kelamin responden. Data mengenai jenis kelamin responden tersaji pada Gambar 1. yang menunjukkan bahwa jumlah responden sebanyak 100 orang dengan jumlah responden perempuan sebanyak 62 orang (62\%) dan laki-laki 38 orang (38\%). Pada Gambar 1 dapat diketahui bahwa jumlah responden dengan rentang usia $18-23$ tahun merupakan jumlah responden yang paling banyak dengan jumlah responden sebanyak 56 orang, sedangkan responden dengan usia $<18$ tahun paling sedikit yaitu berjumlah 1. Responden dengan rentang usia $24-29$ tahun berjumlah 32 orang, sedangkan responden dengan rentang usia 30 - 35 tahun dan usia diatas 36 tahun masing - masing berjumlah 5 dan 6 orang.

Gambar 2 menunjukkan bahwa jumlah responden terbanyak menurut pekerjaan adalah Pegawai Swasta dengan jumlah 45 orang (45\%), sedangkan responden dengan jumlah paling sedikit adalah PNS/TNI/Polri. Pada Gambar 2 dapat diketahui bahwa jumlah responden dengan pendapatan sebesar Rp. 2.500.000 - Rp. 3.500.000 merupakan jumlah yang paling banyak $(32,32 \%)$. Responden dengan pendapatan diatas Rp. 5.000 .001 menjadi responden dengan jumlah paling sedikit yaitu 7 orang. 

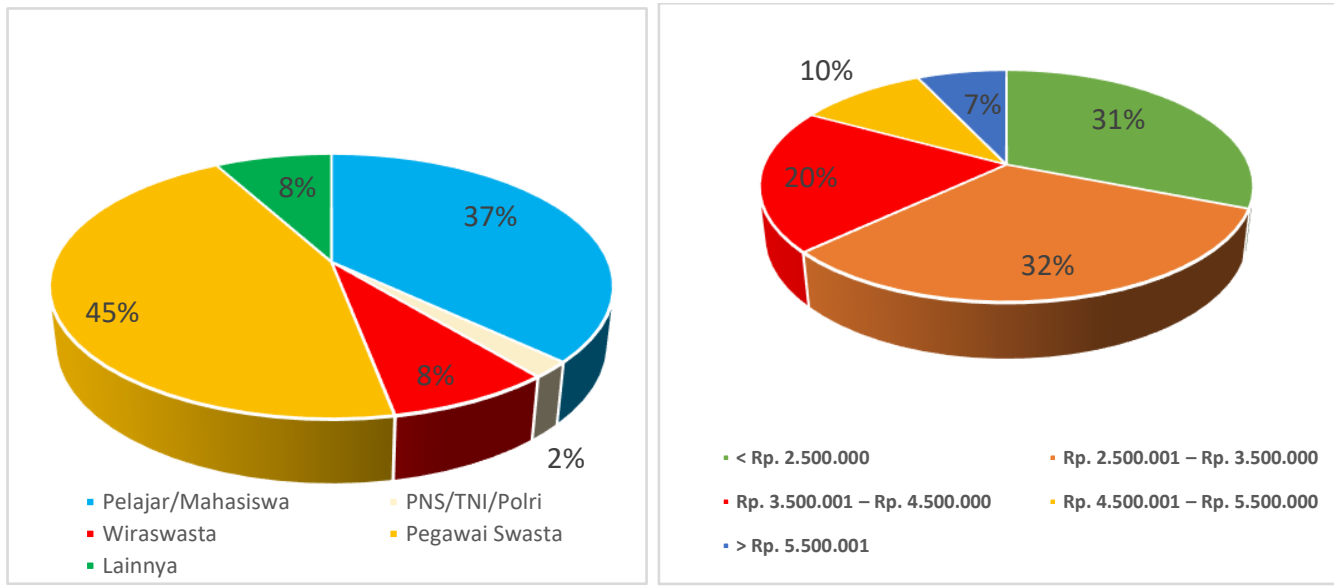

Brand Awareness and Promotional Mix

Gambar 2 Sebaran Responden Berdasarkan pekerjaan dan Penghasilan

Responden dalam penelitian ini lebih banyak minum Yakult sebanyak 2-4 kali dalam seminggu dengan jumlah responden sebanyak 78 orang, sedangkan responden yang meminum Yakult lebih dari 10 kali dalam satu minggu sebanyak 3 orang. Hasil lengkap tersaji pada Gambar 4.5.



Gambar 3 Sebaran Responden Berdasarkan Frekuensi Minum Yakult selama Satu Minggu

\section{Analisis Regresi Berganda}

Analisis regresi berganda dilakukan untuk menguji hipotesis tentang pengaruh secara parsial dan secara simultan variabel independen terhadap variabel dependen. Hasil analisis regresi disajikan pada Tabel 1.

Tabel 1 Hasil Uji Regresi

\begin{tabular}{|c|c|c|c|c|c|}
\hline \multicolumn{6}{|c|}{ Coefficients $^{\mathrm{a}}$} \\
\hline \multirow[t]{2}{*}{ Model } & \multicolumn{2}{|c|}{$\begin{array}{c}\text { Unstandardized } \\
\text { Coefficients }\end{array}$} & \multirow{2}{*}{\begin{tabular}{|c|}
$\begin{array}{c}\text { Standardize } \\
\mathrm{d} \\
\text { Coefficients }\end{array}$ \\
Beta \\
\end{tabular}} & \multirow[t]{2}{*}{$\mathrm{t}$} & \multirow[t]{2}{*}{ Sig. } \\
\hline & B & Std. Error & & & \\
\hline 1 (Constant) & 7.840 & 1.798 & & 4.360 & .000 \\
\hline Personal_selling & .265 & .048 & .524 & 5.359 & .000 \\
\hline Slogan_iklan & .281 & .048 & .529 & 5.815 & .000 \\
\hline
\end{tabular}

a. Dependent Variable: Brand_awareness

Sumber: Hasil olahan kuesioner, 2020

Tabel 1 menunjukkan output SPSS 22 statistic for windows dengan persamaan regresi linier berganda dirumuskan sebagai berikut:

Hasil dari analisis dapat dijelaskan sebagai berikut:

$$
\mathrm{Y}=7.840+0.265 \mathrm{X} 1+0.281 \mathrm{X} 2+\mathrm{e}
$$


Brand Awareness and Promotional Mix
1. Nilai konstanta persamaan diatas sebesar 7.840 angka tersebut menunjukkan bahwa jika X1 (Personal Selling) dan Slogan Iklan (X2), konstan (tidak berubah), maka Brand Awareness adalah sebesar 7.840.

2. X1 (Personal Selling) memiliki nilai koefisien sebesar 0.265 , artinya setiap kenaikan variabel Personal Selling sebesar 1 satuan maka Brand Awareness akan mengalami kenaikan sebesar 0.265 .

3. X2 (Slogan Iklan) memiliki nilai koefisien sebesar 0.281 , artinya setiap kenaikan variabel Slogan Iklan sebesar 1 satuan maka Brand Awareness akan mengalami kenaikan sebesar 0.281 .

Koefisien korelasi merupakan suatu alat yang digunakan untuk mengukur tingkat keeratan hubungan antara variabel independen dengan variable dependen. Nilai $R$ akan berkisar antara $0-1$, semakin mendekati 1 hubungan antara variabel independen secara bersama-sama dengan variabel dependen semakin kuat.

Tabel 2 Hasil Uji Korelasi Variabel

Model Summary

\begin{tabular}{|l|r|r|r|rr|}
\hline Model & $\mathrm{R}$ & R Square & \multicolumn{1}{c|}{$\begin{array}{c}\text { Adjusted } \mathrm{R} \\
\text { Square }\end{array}$} & \multicolumn{2}{|c|}{$\begin{array}{c}\text { Std. Error of the } \\
\text { Estimate }\end{array}$} \\
\hline 1 & $.594^{\mathrm{a}}$ & .352 & .339 & & 1.777 \\
\hline
\end{tabular}

a. Predictors: (Constant), Slogan_iklan, Personal_selling

Sumber: Hasil olahan kuesioner, 2020

Nilai koefisien korelasi yang ditunjukkan pada Tabel 4.12 yaitu 0.594 , dengan demikian dapat dinyatakan bahwa ada hubungan yang positif antara variabel Personal Selling dan Slogan Iklan dengan variabel Brand Awareness yang dikategorikan Sedang,

\section{Koefisien Determinasi $\left(\mathbf{R}^{2}\right)$}

Koefisien Determinasi $\left(\mathrm{R}^{2}\right)$ mengukur seberapa jauh kemampuan model dalam menerangkan variasi variabel dependen (Ghozali 2005). Nilai koefisien determinasi adalah antara 0 (nol) dan 1 (satu). Nilai $\mathrm{R}^{2}$ yang kecil berarti kemampuan variabelvariabel independen dalam menjelaskan variasi variabel dependen amat terbatas. Nilai yang mendekati 1 berarti variabel-variabel independen memberikan hampir semua informasi yang dibutuhkan untuk memprediksi variasi variabel dependen (Ghozali 2005). Pada Tabel 2 diketahui bahwa nilai koefisien determinasi ( $\mathrm{R}$ square) yaitu 0.352 hal ini mengandung arti bahwa 35.2\% variabel Brand Awareness dapat dijelaskan oleh variabel Personal Selling dan Slogan Iklan sedangkan sisanya yaitu 64.8\% dijelaskan oleh sebabsebab yang lain diluar variabel yang belum diteliti.

Uji F (simultan)

Tabel 3 Hasil Uji F (Simultan)

ANOVA $^{b}$

\begin{tabular}{|l|r|r|r|r|r|}
\hline Model & \multicolumn{1}{|c|}{$\begin{array}{c}\text { Sum of } \\
\text { Squares }\end{array}$} & df & $\begin{array}{c}\text { Mean } \\
\text { Square }\end{array}$ & F & Sig. \\
\hline $\begin{array}{l}\text { Regressio } \\
\mathrm{n}\end{array}$ & 166.637 & 2 & 83.318 & 26.381 & $.000^{\mathrm{a}}$ \\
$\quad$ Residual & 306.353 & 97 & 3.158 & & \\
$\quad$ Total & 472.990 & 99 & & & \\
\hline
\end{tabular}

a. Predictors: (Constant), Slogan_iklan, Personal_selling

b. Dependent Variable: Brand_awareness

Penguji simultan merupakan pengujian secara bersama-sama variabel Personal Selling dan Slogan Iklan terhadap Brand Awareness. Jika nilai Fhitung $>$ Ftabel maka variabel bebas (X) tidak berpengaruh terhadap variabel terikat (Y). Jika nilai Fhitung $<$ Ftabel maka variabel bebas $(\mathrm{X})$ tidak berpengaruh terhadap variabel terikat $(\mathrm{Y})$. Jika nilai sig. < 0.05 maka variabel bebas $(\mathrm{X})$ tidak berpengaruh signifikan terhadap variabel terikat (Y). 
jika nilai sig. $>0.05$ maka variabel bebas $(\mathrm{X})$ tidak berpengaruh signifikan terhadap variabel terikat $(\mathrm{Y})$. Nilai Ftabel dapat dilihat pada tabel statistik untuk signifikansi 0.05 dengan $\mathrm{dF} 1=(\mathrm{k}-1)$ dan $\mathrm{dF} 2=(\mathrm{n}-\mathrm{k})$. Dimana $\mathrm{k}=$ jumlah variabel dan $\mathrm{n}=$ jumlah sampel pembentuk regresi. Jadi, $\mathrm{dF} 1=(3-1)=2$ dan $\mathrm{dF} 2=(100-3)=97$. Hasil diperoleh untuk Ftabel sebesar 3.09.

Hasil uji ANOVA atau uji f didapat nilai Fhitung sebesar 26.381, nilai ini lebih besar dari Ftabel yaitu 3.09 atau Fhitung $26.381>$ Ftabel 3.09 dengan probabilitas 0.000. Nilai probabilitas jauh lebih kecil dari 0.05 maka model regresi dapat digunakan untuk memprediksi Brand Awareness atau dapat disimpulkan bahwa kedua variabel bebas Personal Selling dan Slogan IKlan secara bersama-sama berpengaruh terhadap Brand Awareness. Dengan hasil ini maka hipotesis penelitian 1 (Personal Selling, dan Slogan Iklan secara bersamaan mempunyai pengaruh positif dan signifikan terhadap Brand awareness) dapat diterima.

\section{Uji t (Parsial)}

Untuk mengetahui bahwa Personal Selling dan Slogan Iklan berpengaruh secara parsial terhadap Brand Awareness, maka dilakukan uji t. Pengujian ini dilakukan dengan membandingkan $t_{\text {hitung }}$ dengan $t_{\text {tabel }}$ pada taraf nyata $\alpha=0.1$. Apabila hasil perhitungan $t_{\text {hitung }}$ lebih besar dari $t_{\text {tabel }}\left(t_{\text {hitung }}>t_{\text {tabel }}\right)$ atau probabilitas kesalahan lebih kecil dari $5 \%$ (sig $<0.05$ ) maka dapat dinyatakan bahwa X1 dan X2 berpengaruh terhadap Y. Nilai tabel dapat dilihat pada tabel statistik untuk signifikansi 0.05 dengan $\mathrm{df}=\mathrm{n}-\mathrm{k}$. Dimana $\mathrm{k}=$ jumlah variabel dan $n=$ jumlah observasi/sampel pembentuk regresi. Jadi, $\mathrm{df}=100-3=$ 97, maka nilai nilai tabel sebesar 1.66. Adapun hasil uji $t$ dapat dilihat pada Tabel 1 berikut ini: Berdasarkan Tabel 1 menunjukkan bahwa variabel Personal Selling (X1) memiliki thitung sebesar 5.359 dan nilai $t_{\text {tabel }}$ distribusi 5\% sebesar 1.66 sehingga dapat disimpulkan bahwa $\mathrm{t}_{\text {hitung }}>\mathrm{t}_{\text {tabel. }}$. Adapun nilai signifikansinya yaitu $0.000<0.05$ artinya variabel Personal Selling berpengaruh positif dan signifikan terhadap Brand Awareness. Dengan hasil analisis ini maka dapat disimpulkan bahwa Hipotesis penelitian 2 (Personal Selling mempunyai pengaruh positif dan signifikan terhadap Brand awareness) dapat diterima.

Sedangkan untuk variabel Slogan Iklan menunjukkan nilai t-hitung sebesar 5.815 dan nilai pada t-tabel 5\% sebesar 1.66 maka nilai t-hitung $>\mathrm{t}$-tabel. Adapun nilai signifikansi yaitu $0,000<0.05$. Hal ini berarti variabel Slogan IKlan berpengaruh positif dan signifikan terhadap Brand Awareness. Dengan demikian dapat disimpulkan bahwa Hipotesis Penelitian 3 (Slogan Iklan mempunyai pengaruh positif dan signifikan terhadap Brand Awareness).

\section{Pembahasan}

Hasil analisis menunjukkan bahwa responden dalam penelitian ini lebih banyak perempuan dengan rentang usia antara 18 hingga 24 tahun, memiliki pekerjaan sebagai pegawai swasta dengan pendapatan antara Rp. 2.500.001 hingga Rp. 3.500.000. Adapun responden dalam penelitian ini lebih banyak meminum Yakult 2 sampai 4 kali dalam seminggu. Dalam penelitian ini terdapat tiga variabel yang diteliti yaitu Personal Selling (X1), Slogan Iklan (X2) dan Brand Awareness (Y). Variabel Personal Selling dan Slogan Iklan merupakan variabel independen sedangkan variabel Brand Awareness merupakan variabel dependen. Pengujian hipotesis antar variabel independen dan dependen dilakukan dengan menggunakan analisis SPSS 22.

Hasil analisis perhitungan data menggunakan SPSS 22 menunjukkan bahwa terdapat pengaruh yang signifikan pada Personal Selling dan Slogan Iklan terhadap Brand Awareness secara bersama-sama. Secara parsial Personal Selling memiliki pengaruh yang signifikan terhadap Brand Awareness, sedangkan Slogan Iklan memiliki pengaruh yang positif dan signifikan terhadap Brand Awareness. Untuk mengetahui hubungan antara ketiga variabel dilakukan penjelasan sebagai berikut:

a. Personal Selling Berpengaruh Positif Signifikan secara Parsial terhadap Brand Awareness. Hasil analisis menunjukkan bahwa variabel Personal Selling (X1) memiliki $\mathrm{t}_{\text {hitung }}$ sebesar 5.359 dan nilai $\mathrm{t}_{\text {tabel }}$ distribusi 5\% sebesar 1.66 sehingga dapat disimpulkan bahwa $t_{\text {hitung }}>\mathrm{t}_{\text {tabel. }}$. Adapun nilai signifikansinya yaitu $0.000>0.05$ artinya variabel
Brand Awareness and Promotional Mix 
Brand Awareness and Promotional Mix

136
Personal Selling berpengaruh positif signifikan terhadap Brand Awareness. Penelitian ini sejalan dengan penelitian yang dilakukan Syachran (2018), dan Yapilando (2018). Yakult telah ada di Indonesia sejak tahun 1991, artinya sudah hampir tiga dekade masyarakat Indonesia mengenal Yakult, sehingga keberadaan Personal Selling tidak akan berpengaruh terhadap Brand Awareness masyarakat Indonesia mengingat produk Yakult sudah dikenal secara turun temurun. Namun demikian Personal Selling harus tetap menjaga penampilan agar lebih menarik di mata konsumen, dan personal selling juga harus bersikap ramah kepada pelanggan dalam menjelaskan produk maupun memperkenalkan identitas diri.

b. Slogan Iklan Berpengaruh secara Parsial terhadap Brand Awareness.Hasil penelitian menunjukkan bahwa Slogan Iklan mempengaruhi secara signifikan dan positif terhadap Brand Awareness Yakult, dengan nilai t-hitung sebesar 5.815 dan nilai pada t-tabel 5\% sebesar 1.66 maka nilai t-hitung $>$ t-tabel. Adapun nilai signifikansi yaitu $0,000<0.05$. Hasil penelitian ini sejalan dengan penelitian Putri (2012), Fatmawati (2018), Assagaf (2013), Karunanithy dan Sivesan (2013), Gunawan dan Dharmayanti (2014), Sukma et al. (2015), Herdana (2015), serta Charanah dan Njuguna (2015), dalam penelitiannya disebutkan bahwa efektifitas iklan berpengaruh positif dan signifikan terhadap Brand Awareness. Dewi dan Sulistyawati (2018) dalam hasil penelitiannya menyampaikan bahwa meningkatnya kualitas iklan maka akan meningkatkan Brand Awareness. Hasil ini membuktikan bahwa peningkatan iklan secara langsung akan meningkatkan Brand Awareness, karena iklan dengan informasi yang jelas, menarik, frekuensi periklanan yang intensif, dan penayangan iklan di berbagai media yang efektif, akan mampu untuk menimbulkan ketertarikan pada calon konsumen untuk tahu lebih banyak. Dengan ketertarikan tersebut, calon konsumen akan berusaha untuk mencari tahu lebih banyak mengenai produk barang atau jasa tersebut dan itu berarti akan meningkatkan Brand Awareness dari calon konsumen dengan banyaknya informasi baru yang didapatkannya. Hal itu dikarenakan merek akan menjadi merek yang semakin dikenal, dan semakin mudah untuk diingat, saat informasi pada calon konsumen semakin bertambah dan pada akhirnya saat calon konsumen memutuskan untuk membeli sebuah merek maka yang pertama kali diingat adalah merek tersebut. (Prabawa et al., 2017). Perusahaan Yakult diharapkan lebih meningkatkan program iklan dengan program yang lebih menarik dan menggunakan media yang lebih tepat guna meningkatkan Brand Awareness serta keputusan pembelian konsumen Yakult. Selain itu, perusahaan Yakult sebaiknya mempertimbangkan sarana promosi lainnya di samping iklan agar kinerja dan tujuan perusahaan dapat tercapai dengan lebih baik.

c. Personal Selling dan Slogan Iklan Berpengaruh secara Simultan terhadap Brand Awareness. Berdasarkan hasil pengujian hipotesis yang telah dilakukan diperoleh $\mathrm{f}_{\text {hitung }}$ sebesar 26.381 dengan probabilitas 0.000 yaitu nilai $\mathrm{f}_{\text {hitung }} 26.381>\mathrm{f}_{\text {tabel }} 3,09$. Karena nilai probabilitas jauh lebih kecil dari 0.05 maka dapat dikatakan bahwa variabel Personal Selling dan Slogan Iklan secara bersama-sama berpengaruh positif dan signifikan terhadap Brand Awareness Yakult di Kota Bogor. Hasil penelitian ini sejalan dengan penelitian yang dilakukan oleh Prabawa et al. (2017). yang mengungkapkan bahwa iklan dan personal selling berpengaruh positif dan signfikan terhadap Brand Awareness, jika personal selling dan iklan dari sebuah perusahaan semakin baik, maka potensi Brand Awareness masyarakat terhadap perusahaan tersebut juga akan semakin meningkat, sebaliknya jika konsumen tidak memiliki ketertarikan terhadap personal selling maupun iklan yang dilakukan oleh perusahaan maka potensi Brand Awareness yang dimiliki oleh konsumen juga akan rendah. Namun demikian Hardiyanzah menyatakan hal yang berbeda, dalam penelitiannya disimpulkan bahwa semakin tinggi daya tarik iklan belum tentu semakin tinggi Brand Awareness suatu produk, dan semakin tinggi Personal Selling maka akan semakin tinggi Brand Awareness suatu produk. 


\section{PENUTUP}

Penelitian ini mengkaji tentang pengaruh Personal Selling dan Slogan Iklan terhadap Brand Awareness produk Yakult, dengan tujuan untuk mengetahui pengaruh dari Personal Selling dan Slogan Iklan terhadap Brand Awareness baik secara parsial maupun simultan. Berdasarkan hasil analisis dengan menggunakan SPSS 22, dapat disimpulkan bahwa:

1. Personal Selling memiliki pengaruh yang positif dan signifikan terhadap Brand Awareness, sehingga dapat disimpulkan bahwa melakukan Personal Selling sebagai alat promosi agar mempermudah konsumen dalam mengetahui spesifikasi produk Yakult sehingga tercipta Brand Awareness.

2. Slogan Iklan memiliki pengaruh yang positif dan signifikan terhadap Brand Awareness. Iklan menjadi hal yang penting dalam mengenalkan sebuah produk karena iklan dengan informasi yang jelas, menarik, frekuensi periklanan yang intensif, dan penayangan iklan di berbagai media yang efektif, akan mampu untuk menimbulkan ketertarikan pada calon konsumen untuk tahu lebih banyak.

3. Personal selling dan slogan iklan memiliki pengaruh yang positif dan signifikan terhadap Brand Awareness Yakult secara simultan, sehingga dapat disimpulkan bahwa semakin baik personal selling dan slogan ikan maka Brand Awareness juga akan semakin meningkat, sebaliknya jika konsumen tidak memiliki ketertarikan terhadap personal selling maupun iklan yang dilakukan oleh perusahaan maka potensi Brand Awareness yang dimiliki oleh konsumen juga akan rendah.

\section{DAFTAR PUSTAKA}

[1] Aaker, D.A., 1995. Strategic Market Management Edisi Keempat. New York: John Wiley dan Sons, Inc.

[2] Anton, Howard, 1994, Elementary Linear Algebra Application Version Seventh Edition, John Wiley \& Sons, Inc., United States of America.

[3] Arnold. 2009. Work Psychology: Understanding Human Behavior In The Workplace. London: Financial Time man.

[4] Basu Swastha, 2000, Pengantar Bisnis Modern, Pengantar Ekonomi Perusahaan Modern, Jakarta: Liberty.

[5] Charanah, J. dan Njuguna, R. K . 2015. The Effects Of Promotional Mix Tools On Brand Equity Among Hospitals In Nairobi County. International Journal Of Sales, Retailing And Marketing, 4(6):45-51.

[6] Dewi, Vidya Chandra dan Sulistyawati, Eka. 2018. Peran Brand Awareness Memediasi Pengaruh Iklan terhadap Niat Beli. E-Jurnal Manajemen Unud. 7 (4): 1742-1770. DOI: https://doi.org/10.24843/EJMUNUD.2018.v7.i04.p02.

[7] Darmanto Durianto, Sugiarto, Lie Joko Budiman (2004). Brand Equity Ten: Strategi Memimpin Pasar. Jakarta: PT. Gramedia Pustaka Utama.

[8] James, Bettman. (1973). Perceived Risk and Its Components: A Model and Empirical Test. Journal of Marketing Research, hal 184.

[9] Gunawan, F. A. dan Dharmayanti, D. 2014. Analisis Pengaruh Iklan Televisi dan Endorser terhadap Purchase Intention Pond's Men dengan Brand Awareness sebagai Variabel Intervening. Jurnal Manajemen Pemasaran Petra, 2(1):1-14.

[10] Herdana, A. 2015. Analisis Pengaruh Brand Awareness pada Produk Asuransi Jiwa Prudential Life Assurance (Studi pada Pru Passion Agency Jakarta). Jurnal Riset Bisnis dan Manajemen, 3(1):1-18.

[11] Karunanithy, M. dan Sivesan, S. 2013. An Empirical Study on the Promotional Mix and Brand Equity: Mobile Service Providers. Industrial Engineering Letters, 3(3):1-9.

[12] McCarthy, E.J \& William. Jr.P. 2005. Basic Marketing . 15th edition. Richard D. Irwin. inc .
Brand Awareness and Promotional Mix 
Brand Awareness and Promotional Mix

138
[13] Prabawa Kadek Teddy Surya, Sukawati Tjok Gde Raka, Setiawan Putu Yudi. 2017. Peran Brand Awareness dalam Memediasi Hubungan Iklan dan Personal Selling dengan Niat Beli. E-Jurnal Manajemen Unud. 6 (1): 889-918.

[14] Pitta, D. A. and Katsanis, L. P., 1995, Understanding brand equity for successful brand extension. Journal of Consumer Marketing, Vol. 12, No.4, pp: 51-64.

[15] Rangkuti, Freddy (2002). The Power of Brand. Jakarta: PT. Gramedia Pustaka Utama. Schiffman, L.G. dan Kanuk, L.L. (terj.) (2004). Perilaku Konsumen. Edisi ketujuh: Prentice Hall International.Rossiter dan Perc dalam Olivia Susanti (2007).

[16] Rossiter, J.R., dan Percy, L. (1985). Advertising Communication Models. Advances in Consumer Research, Vol. 12.

[17] Sukma, F., Sarma, M., dan Syamsun, M. 2015. Efektivitas Iklan dalam Menumbuhkan Brand Awareness SMA Sampoerna The Effectiveness of Advertisement in Gaining Brand Awareness of Sampoerna High School. Manajemen IKM, 10(2):182-193.

[18] Yoestini dan Eva Sheila R. 2007. Jurnal Sains Pemasaran Indonesia. Vol.VI. (3): 261276. Jakarta.Abiromo Baskorohito, A. 2014. Pengaruh Tagline Dan Brand Ambassador Terhadap Brand Awarenes Produk Kartu Perdana Simpati (Studi Kasus Pada Mahasiswa Fakultas Ekonomi Universitas Negeri Yogyakarta) (Doctoral dissertation, Fakultas Ekonomi).

[19] Andini, Widya Herliana, 2016, "Faktor-Faktor yang Berpengaruh Terhadap Ketepatan Waktu Penyampaian Laporan Keuangan (Studi Empiris pada Perusahaan Manufaktur yang Terdaftar di Bursa Efek Indonesia Tahun 2012-2014", Skripsi, Universitas Bakrie, Jakarta.

[20] Fatmawati, F. 2018. Pengaruh IKlan Televisi, Tagline, dan Personal Selling terhadap Brand Awareness serta Dampaknya pada Keputusan Pembelian Susu Fermentasi Merek Yakult di Kecamatan Kebumen. Sekolah Tinggi Putra Bangsa Kebumen. Jawa Timur.

[21] Harahap, Chindy Fairuz Talitha. 2016. Pengaruh Kualitas Pesan Iklan, Selebriti Pendukung, Dan Penggunaan Tagline Iklan Di Televisi Terhadap Pembentukan Brand Awareness Produk Le Minerale Pada Mahasiswa Fakultas Ilmu Sosial Dan Ilmu Politik Universitas Sumatera Utara. Medan. FE USU

[22] Hardianzah, C. 2014. Pengaruh Daya Tarik Iklan dan Personal Selling terhadap Brand Awareness Minuman Isotonik Mizone (Studi Pada Indomaret Lakarsantri Surabaya). Skripsi. Fakultas Ekonomi Universitas Pembangunan Nasional "Veteran" Jawa Timur. Jawa Timur.

[23] Putri Ryanthi Damanti. 2012. Pengaruh Advertising terhadap Brand Awareness serta Dampaknya pada Keputusan Pembelian Produk Kecap Indofood (Survei KOnsumen Kecap di Kelurahan Turangga). Skripsi. Fakultas Bisnis dan Manajemen Universitas Widyatama. Bandung

[24] Rahma, Eva Sheilla. (2007). Analisis Pengaruh Kalias Merek Terhadap Minat Beli dan dampaknya Pada Keputusan Pembelian (Studi Pada Pengguna Telepon Seluler Merek Sony Ericson Di Kota Semarang). Tesis. Semarang, Universitas Diponegoro.

[25] Syachran, Fany. 2018. Pengaruh Iklan dan Personal Selling terhadap Brand Image Indosat di Kota Makassar. Skripsi. Fakultas Ekonomi dan Bisnis Islam UIN Alauddin Makassar.

[26] Yapilando, Monica. 2018. Pengaruh Komunikasi Pemasaran Hotel Ciputra World terhadap Brand Awareness Masyarakat Surabaya. Jurnal E-Komunikasi, 6(1): 1-11

[27] Yudhiartika, D., dan Haryanto, J. O. 2012. Pengaruh Personal Selling, Display, Promosi Penjualan terhadap Brand Awareness dan Intensi Membeli pada Produk Kecantikan Pond's. Buletin Studi Ekonomi, 17(2):142-156.

[28] Zulianto, Eko. 2010. Analisa Pengaruh Pengguna Tagline dan Persepsi konsumen dalam Membentuk Brand Awareness Suatu Produk Oleh Mahasiswa Universitas Islam Negeri Syarif Hidayatulah Jakarta. Skripsi Fakultas Ekonomi Universitas Islam Negeri Syarif Hidayatullah Jakarta. 